\title{
PERFORMANCE CHARACTERISTICS OF HOPKINSON'S SET-UP PNEUMATIC LAUNCHER
}

\author{
Kamil Sobczyk, Leopold Kruszka*, Ryszard Chmielewski, \\ RYSZARD REKUCKI
}

\author{
Military University of Technology, Faculty of Civil Engineering and Geodesy, Department of Military \\ Engineering and Military Infrastructure, 2 Gen. Sylwester Kaliski Str., 00-908 Warsaw, Poland \\ * corresponding author: leopold.kruszka@wat.edu.pl
}

\begin{abstract}
The paper presents a performance characteristics of a pneumatic launcher, which is an important element of the split Hopkinson bar set-up (SHPB) at the Department of Military Engineering and Infrastructure (the Military University of Technology in Warsaw) for the purpose of dynamic strength tests of construction materials. The process of experimental calibration of the launcher for selected loading bar-projectiles is shown. Two types of compression during direct impact tests were also used simultaneously to investigate the behaviour of metallic samples with the use of this launcher as well as the Hopkinson measuring bar: the first - a short cylindrical sample, including a miniature (small diameter) sample, and the second - a long cylindrical sample (Taylor test). The relationships describing the stress and strain state as a function of strain rate for the first type of the experiment and engineering empirical formulas for the second type of the research were given.
\end{abstract}

KEYWORDS: Pneumatic launcher, Hopkinson measuring bar, direct impact tests.

\section{INTRODUCTION}

The beginnings of the development of gas launchers are related to a military technology. The design of the pneumatic guns used to launch large-diameter missiles was first presented by D. M. Medford in 1883 in Fort Hamilton (USA). However, the first land-based air cannons designed by the American inventor born in Kórnik (Poland), Major Edmund Żaliński, were installed in 1894 at Sandy Hook Fort in New Jersey. It was a three-gun battery of 15 -inch $(381 \mathrm{~mm})$ coastal artillery guns operating in a similar way to an air gun: compressed air was used to fire a projectile (explosive charge) [1. In 1900, Żaliński's triple air gun was installed on the USS Vesuvius, and a twin 8.425 in $(214 \mathrm{~mm})$ on the Holland IV submarine, known as Zalinski Boat, designed by Edmund Żaliński and John Holland. The rapid development of fuel and missiles in the late 1890s and early 1900s led to the creation of gunpowder guns and caused pneumatic guns to be substantially phased out from the US Army starting in 1905.

Currently, pneumatic guns are designed to carry out various research impact tests, with various energy possibilities, limited by the diameter and working pressure 2]. Small-diameter systems (up to $70 \mathrm{~mm}$ ) allow for higher velocities for smaller-mass projectiles, while in medium-diameter solutions $(70-150 \mathrm{~mm})$ for objects with larger mass, the muzzle velocity is lower. The greatest drop in speed is recorded for large-diameter devices (over $200 \mathrm{~mm}$ ).

The small-diameter pneumatic launcher is an important element of the stationary test stand called the split Hopkinson pressure bar SHPB [3]. This stand is intended for testing the behaviour of samples of construction materials, including construction materials subjected to impact loads [4] and in the field metals [5-9] as well as for concretes [10, polymers, wood, soils [11]15] and other materials [16]18. Understanding the dynamic strength characteristics of these materials is important for the design of protective structures for buildings, especially in the conditions prone to industrial accidents [19, to ensure safety [20]. With the use of compressed air, the launcher on this test stand allows for throwing projectiles, such as a bar or Hopkinson measuring bars, directly loading the tested metallic sample, U. S. Lindholm used a spring and then a pneumatic 0.5 inch $(12.7 \mathrm{~mm})$ launcher in the SHPB test stand for the first time at the beginning of the 1960s [21]. Until then, blasting shots have been used to generate a stress pulse in Hopkinson measuring bars.

The stationary pneumatic launcher, which is an element of the SHPB, intended to test the behaviour of material samples subjected to dynamic (shock) loads, does not meet the statutory definitions of "firearms", "gun" and "pneumatic weapons" 22. This means that pursuant to the Act of June 13, 2019 on the performance of economic activity in the field of production and trade in explosives, weapons, ammunition, and products and technology for military or police purposes [23] it is not considered a weapon. However, if the pneumatic launcher in question was designed and intended solely for the production or certification, qualification or testing of products included in Part IV - WT of the Annex to the Regulation [24, then it would be subject to regulation resulting from the provisions of the Act [25]. The contractor of such 


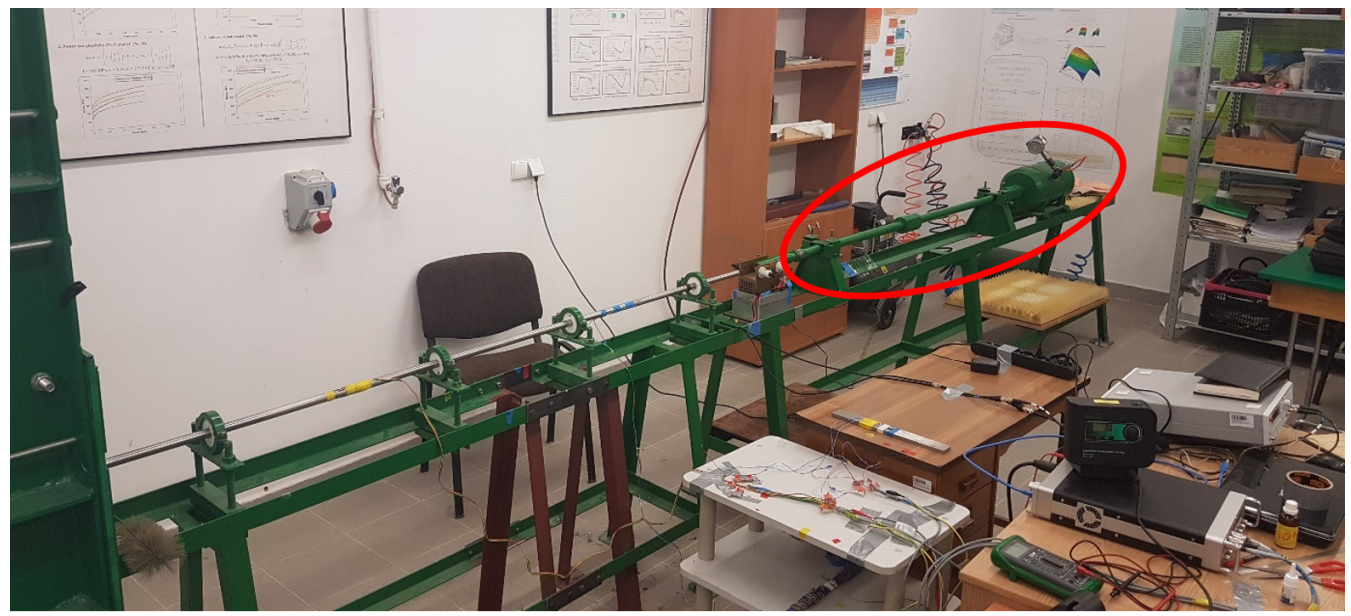

FIgURE 1. General view of the SHPB test stand DMEI (MUT) - on the right side of the test stand, there is a pneumatic launcher (the pressure chamber with the barrel are marked with a red ellipse).

a pneumatic launcher would have to have a license granted by the Minister of the Interior and Administration, at least in the scope of manufacturing and trading in products for military or police purposes specified in WT XIII section 1 or 2 depending on:

- a type of equipment specially designed or modified for the production of products covered by Part IV — WT, and specially designed components thereof;

- the type of a specially designed facility for conducting environmental tests and the type of specially designed equipment for the purpose of certification, qualification or testing of products included in the list contained in Part IV - WT.

At present, the disadvantages of split Hopkinson bars, such as the high air operating pressures to obtain high strain rates, the noise due to the instantaneous air expansion, and a large overall station length, have been eliminated in the electromagnetic Hopkinson bar. It uses the intense pressure created in the magnetic field created by the passage of an electric current pulse through a series of coils. The magnetic field behaves like the release of air from a high-pressure vessel and can impart a high initial velocity to the bar-projectile to obtain very high compressive and strain rates of metallic materials, more than $10^{4} 1 / \mathrm{s}$. However, for low and medium impact velocities of this projectile, pneumatic launchers are still useful for conducting physical experiments in the range of deformation rates $10^{2}-10^{3} 1 / \mathrm{s}$. They ensure a good reproducibility of obtaining the value of the impact velocity for individual set values of the deformation rate. However, from the point of view of objectivity of dynamic tests, it is necessary to conduct preliminary tests to validate the pneumatic launcher, a so-called calibration procedure, before a series of physical experiments to obtain empirical relationships between the working pressure and the impact velocity for the geometric parameters of the bar-projectile used in further tests, which characterize the performance of this launcher.
This is especially important during various schemes for material impact tests with the use of the pneumatic launcher. The subject of this work is devoted to these issues.

\section{CHARACTERISTICS OF THE PNEUMATIC LAUNCHER OF THE SHPB STAND}

The subject of the work is a pneumatic launcher included in the split Hopkinson bar testing stand (shown in Figure 11, which is located at the Department of Military Engineering and Infrastructure (DMEI) of the Military University of Technology (MUT) in Warsaw.

The pneumatic launcher consists of a pressure chamber with a capacity of $10 \mathrm{dm}^{3}$ with a smooth barrel with a diameter of $20 \mathrm{~mm}$ and a length of $2700 \mathrm{~mm}$. Figure 2 shows a general view of the launcher and shows the valve with a digital pressure gauge that feeds the launcher chamber and the valve supplying the space behind the bar-projectile in the barrel.

The launcher in question is fed with compressed air from a compressor to a maximum working pressure $p_{\max }=8$ bar. The important elements of this pneumatic system are:

- air compressor type Specair HL 275/50 (Figure 3);

- filter-reducer with a pressure gauge, connected by flexible spiral hoses with the compressor and the pneumatic launcher (Figure 4).

The launcher in question throws bar-projectiles of different lengths, it depends on the conditions of the physical experiment that is carried out on this test stand. Typical bar-projectiles are 100, 200 and $250 \mathrm{~mm}$ in length (Figure 5). Detailed parameters of these bar-projectiles are presented in the Table 1. 


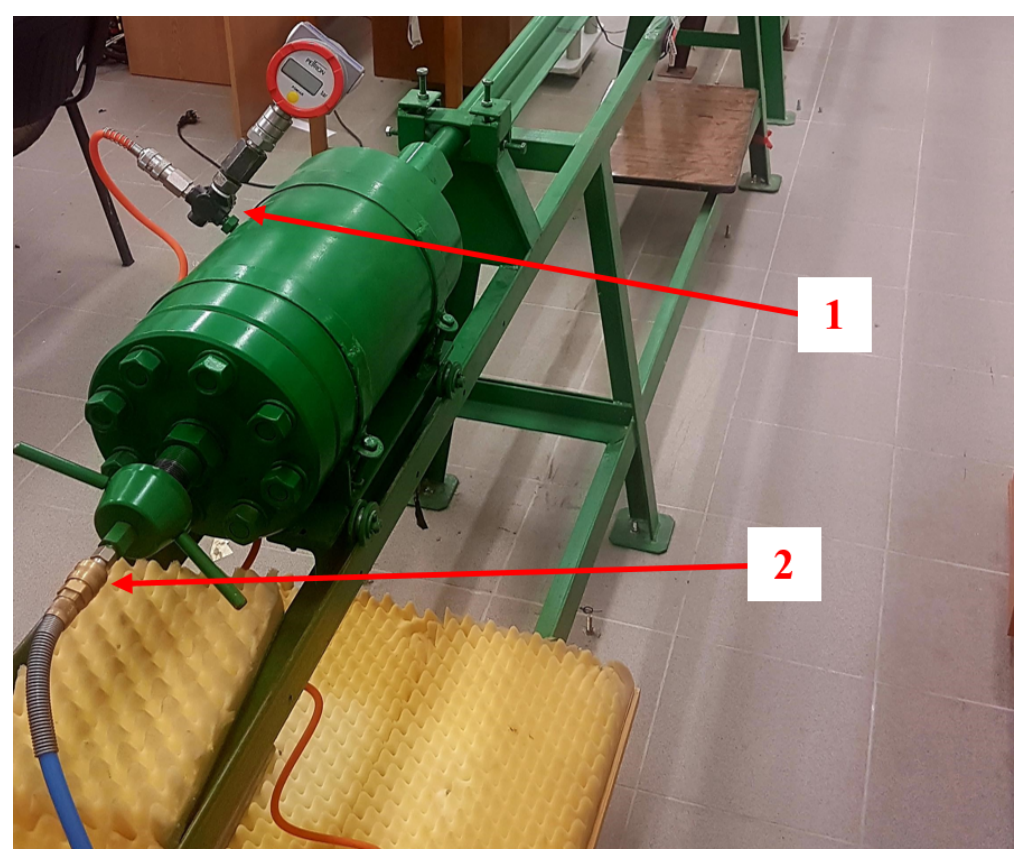

FIGURE 2. General view of the pressure chamber of the pneumatic launcher: 1 - valve with a digital pressure gauge that feeds the launcher chamber, 2 - valve supplying the space behind the bar-projectile in the barrel.

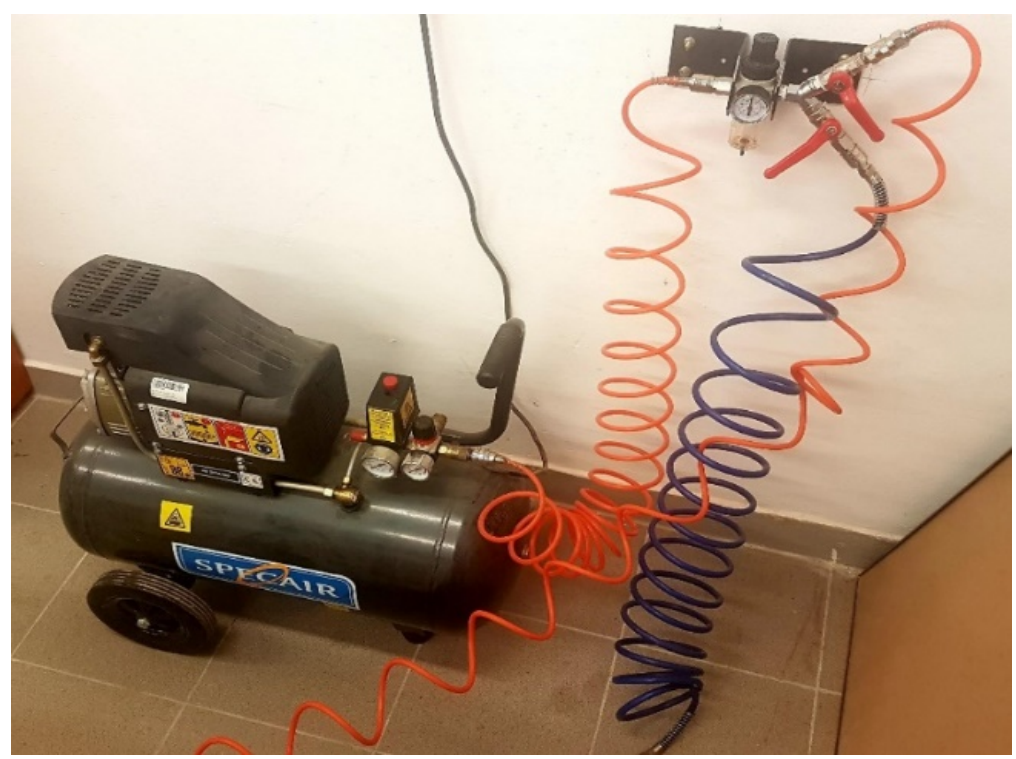

FiguRE 3. Air compressor type Specair HL 275/50.

\begin{tabular}{lccc}
\hline & \multicolumn{3}{c}{ Bar-projectile } \\
\cline { 2 - 4 } & Type 1 & Type 2 & Type 3 \\
\hline Length $L_{b p}[\mathrm{~mm}]$ & 99.10 & 199.40 & 249.80 \\
Weight $m_{b p}[\mathrm{~g}]$ & 234.91 & 353.72 & 491.04 \\
Diameter $D_{b p}[\mathrm{~mm}]$ & 19.92 & 19.97 & 19.96 \\
Material & \multicolumn{3}{c}{ Steel C350 } \\
Modulus of longitudinal elasticity material $E[\mathrm{GPa}]$ & \multicolumn{3}{c}{500} \\
Wave propagation velocity $c_{0}\left[\mathrm{~m} \cdot \mathrm{s}^{-1}\right]$ & \multicolumn{3}{c}{5000} \\
\hline
\end{tabular}

TABLE 1. Detailed parameters of typical bar-projectiles. 


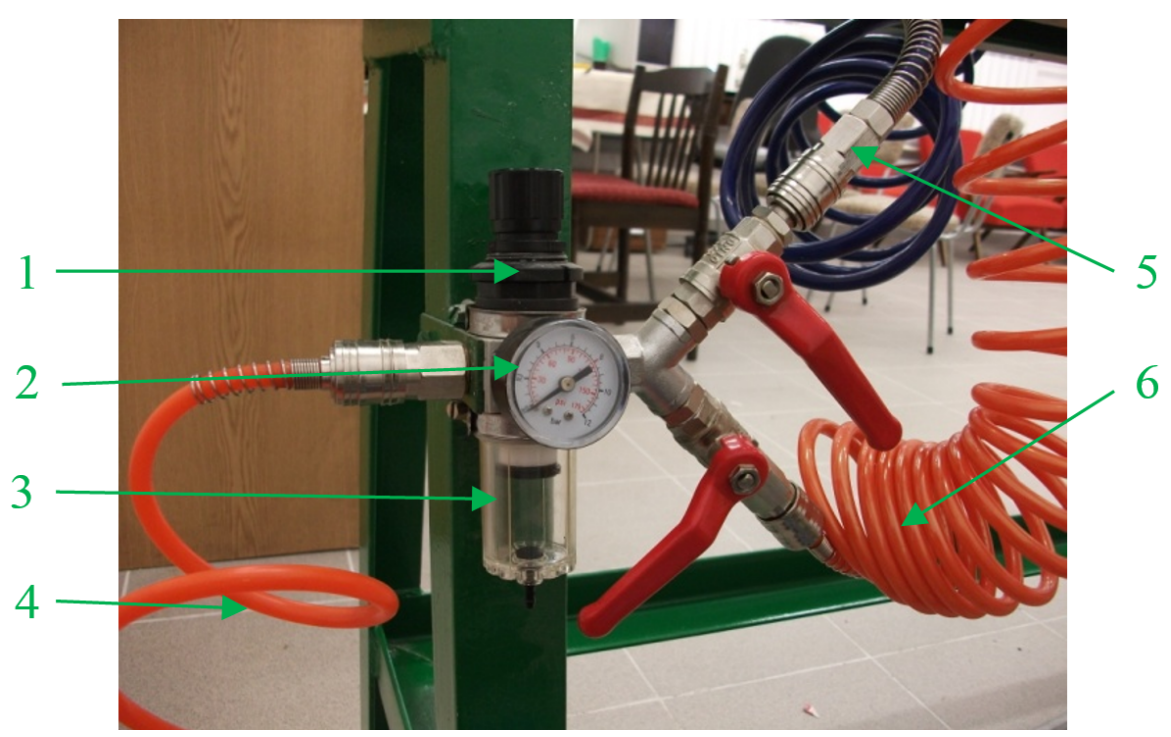

FiguRE 4. Filter-reducer with connections and manometer: 1 - pressure regulator, 2 - pressure gauge, 3 - filter, 4 - spiral tube (connected to the compressor), 5 - spiral tube (connected to the launcher chamber), 6 - spiral tube connected to the barrel part behind the bar-projectile.

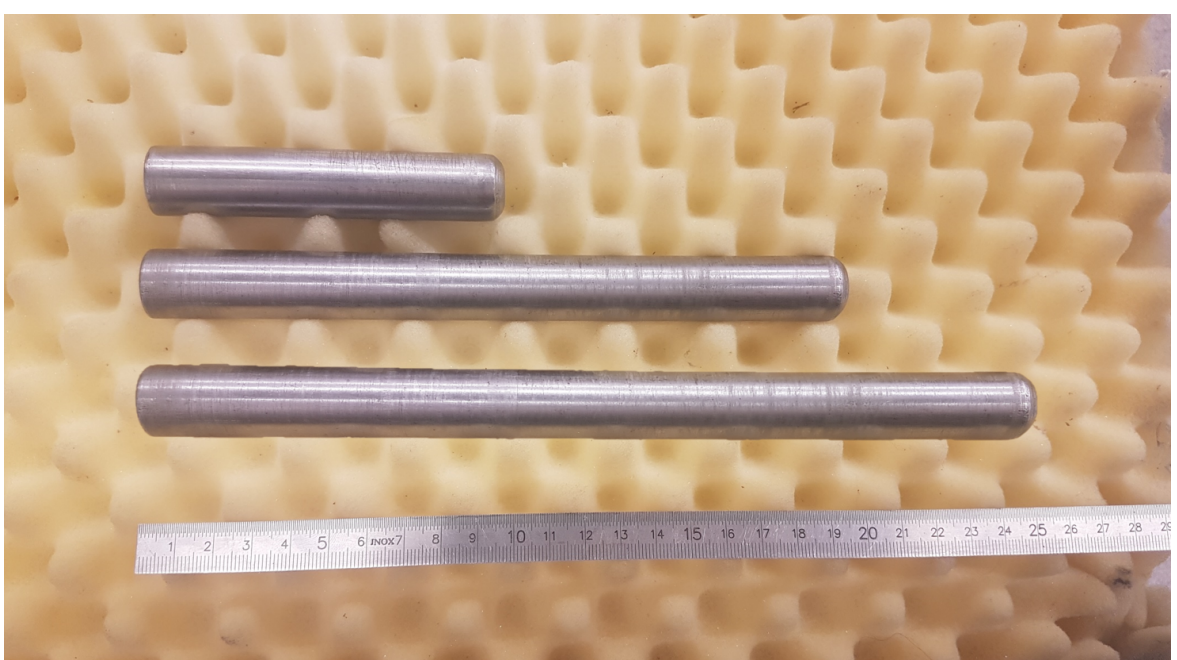

FiguRE 5. Typical bar-projectiles are 100, 200 and $250 \mathrm{~mm}$ in length.

\section{Pneumatic Launcher CAlibration PROCEDURE}

The pneumatic launcher was calibrated for the barprojectiles used. This procedure included measurements of the velocity $v_{0}$ of the bar-projectile at the moment of leaving the barrel for different lengths $L_{b p}$ of the bar-projectile $\left(L_{b p 1}=100 \mathrm{~mm} ; L_{b p 2}=200 \mathrm{~mm}\right.$; $\left.L_{b p 3}=250 \mathrm{~mm}\right)$ in a cycle of five experiments $(i=$ measurement projectile number) in three variants of the operating pressure $p_{0}$ of the pneumatic launcher $\left(p_{01}=0,5\right.$ bar $; p_{02}=1,0$ bar $; p_{03}=1,5$ bar $)$.

The standard deviation for each cycle of five experiments was calculated according to the formula:

$$
\sigma=\sqrt{\frac{1}{n} \cdot \sum_{i=1}^{n}\left(x_{i}-\bar{x}\right)^{2}}
$$

The results of the calibration of the launchers are shown in Table 2

The results contained in Table 2 are presented graphically as diagrams of the muzzle velocity $v_{0}$ of the bar-projectile depending on: a) the working pressure $p_{0}$ of the pneumatic launcher and b) the number of the experimental attempt in three variants of the initial pressure $p_{0}$ for the length $L_{b p}$ of the bar-projectile:

- $L_{b p 1}=100 \mathrm{~mm}$ - Figure 6a and 6b.

- $L_{b p 2}=200 \mathrm{~mm}$ - Figure 7a and 7b.

- $L_{b p 3}=250 \mathrm{~mm}$ - Figure 8a and 8b.

\section{IMPACT TESTS WITH THE USE OF AN SHPB PNEUMATIC LAUNCHER}

Using the SHPB pneumatic launcher, it is possible to use the schemes of two types of compression impact tests for the purpose of testing the behaviour of 


\begin{tabular}{|c|c|c|c|c|}
\hline \multirow{2}{*}{$\begin{array}{l}\text { Length } L_{b p} \\
\text { of the bar-projectile } \\
{[\mathrm{mm}]}\end{array}$} & \multirow[b]{2}{*}{$\begin{array}{l}\text { Attempt } \\
\text { number }\end{array}$} & \multicolumn{3}{|c|}{$\begin{array}{l}\text { The velocity } v_{0 i} \text { of the bar-projectile } \\
\text { at the moment of exiting the barrel }[\mathrm{m} / \mathrm{s}]\end{array}$} \\
\hline & & $\begin{array}{c}p_{01}=0.5 \mathrm{bar} \\
(0.05 \mathrm{MPa})\end{array}$ & $\begin{array}{c}p_{02}=1.0 \mathrm{bar} \\
(0.10 \mathrm{MPa})\end{array}$ & $\begin{array}{c}p_{03}=1.5 \mathrm{bar} \\
(0.15 \mathrm{MPa})\end{array}$ \\
\hline \multirow{5}{*}{100} & 1) & 4.2728 & 14.4931 & 22.0418 \\
\hline & 2) & 4.6167 & 11.6163 & 21.1648 \\
\hline & 3) & 2.7173 & 14.1429 & 22.3073 \\
\hline & 4) & 4.0480 & 15.2419 & 21.9018 \\
\hline & 5) & 3.8620 & 13.8606 & 20.6063 \\
\hline \multirow{2}{*}{$\begin{array}{l}\text { Average velocity values } v \\
\text { Standard deviation } \sigma_{0 i}\end{array}$} & $v_{0 i}$ & 3.9034 & 13.8709 & 21.6044 \\
\hline & & 0.6442 & 1.2185 & 0.6266 \\
\hline \multirow{5}{*}{200} & 1) & 6.5917 & 14.3951 & 19.0846 \\
\hline & 2) & 7.4256 & 14.8395 & 19.0956 \\
\hline & 3) & 8.1195 & 14.6096 & 19.2573 \\
\hline & 4) & 7.6029 & 13.7991 & 19.9091 \\
\hline & 5) & 8.0451 & 13.7009 & 20.1823 \\
\hline \multirow{2}{*}{$\begin{array}{l}\text { Average velocity values } \\
\text { Standard deviation } \sigma_{0 i}\end{array}$} & $v_{0 i}$ & 7.5569 & 14.2688 & 19.5058 \\
\hline & & 0.5488 & 0.4474 & 0.4534 \\
\hline \multirow{5}{*}{250} & 1) & 6.6579 & 11.9606 & 16.6895 \\
\hline & 2) & 7.9015 & 12.7004 & 16.7397 \\
\hline & 3) & 7.6272 & 12.8853 & 16.5981 \\
\hline & 4) & 8.3620 & 12.1925 & 16.2739 \\
\hline & 5) & 9.0590 & 11.5410 & 16.5953 \\
\hline \multirow{2}{*}{$\begin{array}{l}\text { Average velocity values } \\
\text { Standard deviation } \sigma_{0 i}\end{array}$} & $\overline{v_{0 i}}$ & 7.9215 & 12.2560 & 16.5793 \\
\hline & & 0.7964 & 0.4891 & 0.1623 \\
\hline
\end{tabular}

TABLE 2. Summary of the obtained muzzle velocities $v_{0 i}$ of the bar-projectiles for different variants of the length $L_{b p}$ of the bar-projectile and the working pressure $p_{0}$ of the pneumatic launcher.

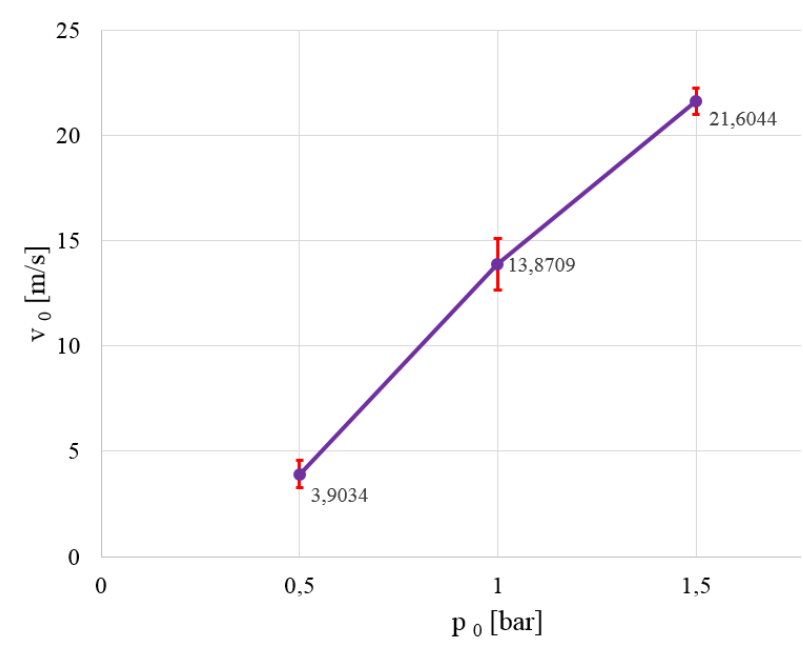

(A).

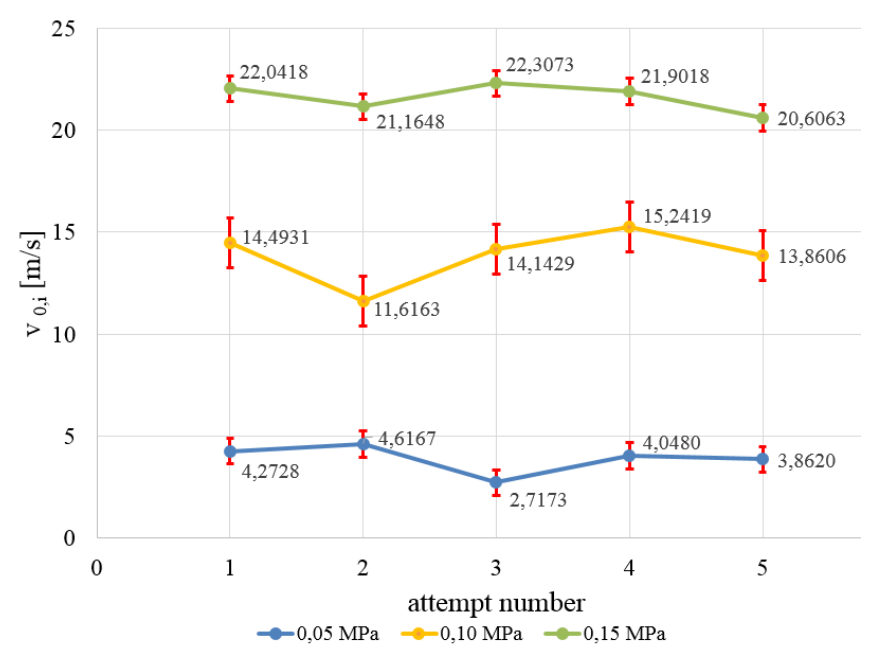

(в).

Figure 6. Dependency graph a) $v_{0}\left(p_{0}\right)$ and b) $v_{(0, i)}\left(i\right.$ - number of the experimental attempt) for $L_{b p 1}=100 \mathrm{~mm}$. 


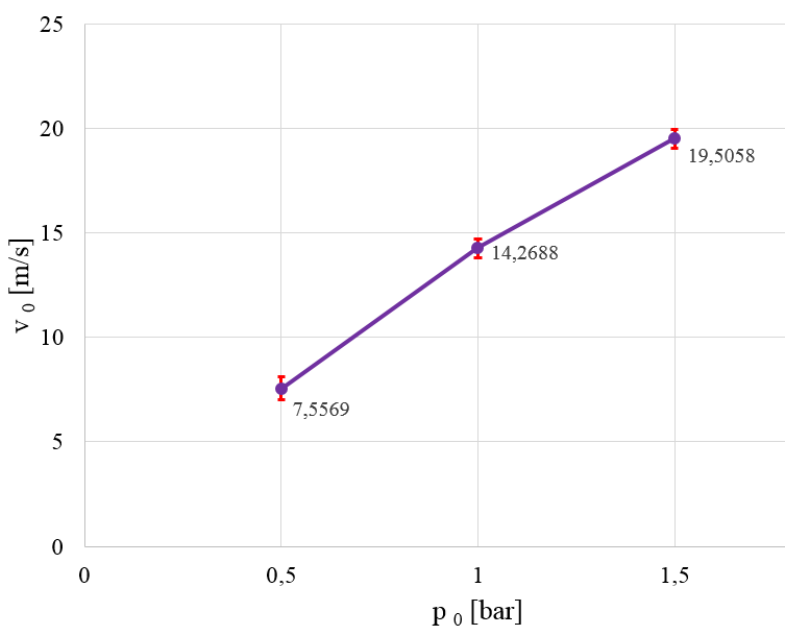

(A).

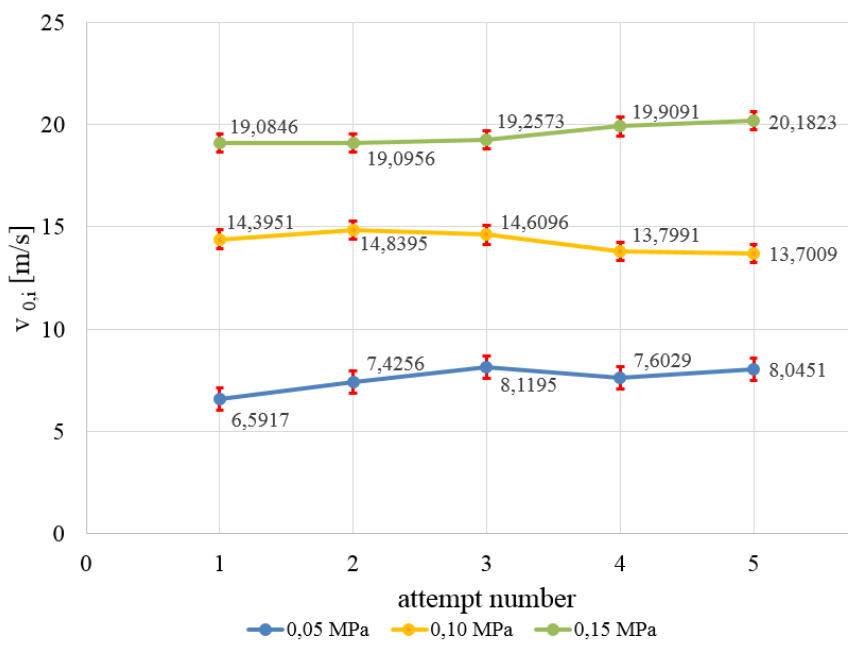

(в).

FIgURE 7. Dependency graph a) $v_{0}\left(p_{0}\right)$ and b) $v_{(0, i)}\left(i\right.$-number of the experimental attempt) for $L_{b p 2}=200 \mathrm{~mm}$.

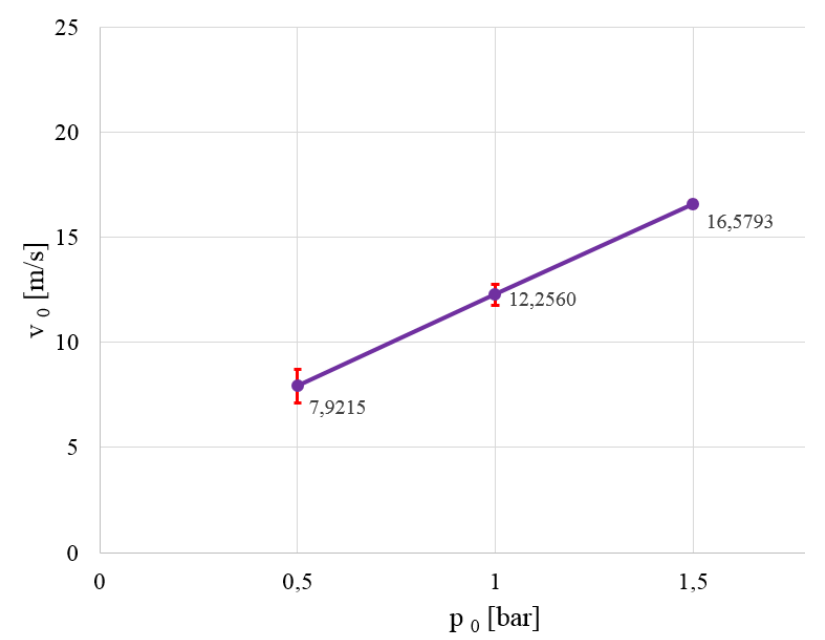

(A).

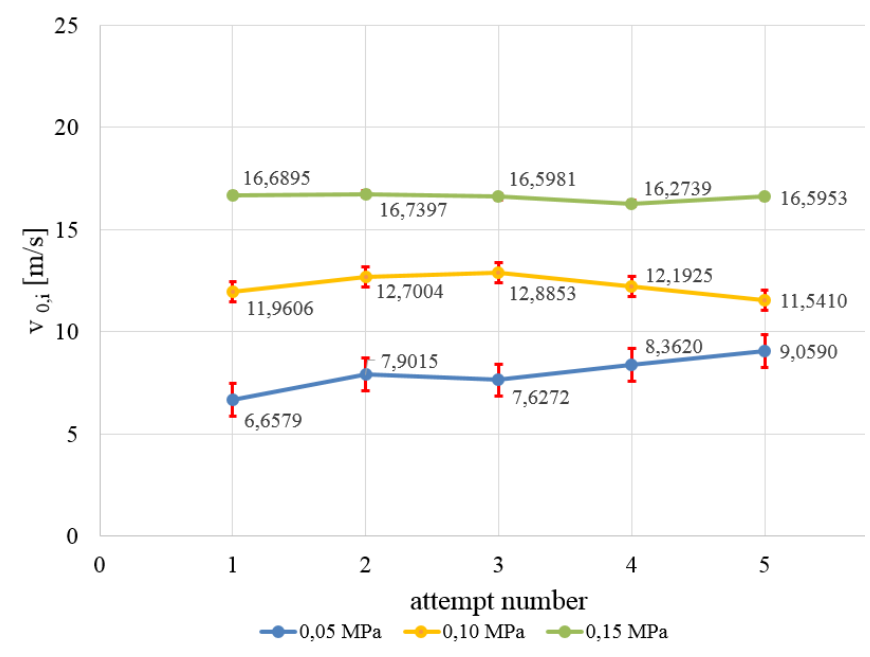

(B).

Figure 8. Dependency graph a) $v_{0}\left(p_{0}\right)$ and b) $v_{(0, i)}\left(i\right.$-number of the experimental attempt) for $L_{b p 3}=250 \mathrm{~mm}$.

metallic samples: the first - a short cylindrical sample, including a miniature (small diameter) sample, and the second - a long cylindrical sample (Taylor test). Along with the diagrams, the formulas for both variants of direct compression are presented to determine the stress $\sigma_{s}$, strain $\varepsilon_{s}$ and strain rate $\dot{\varepsilon}_{s}$ in the engineering (nominal) measure, and for the Taylor impact test - empirical formulas for calculating the initial dynamic yield stress proposed by Taylor $\sigma_{y}^{T}$ and Wilkins and Guinana $\sigma_{y}^{W G}[26]$ are presented.

(1.) Two variants of direct compression of the first type:

(a) variant I of a miniature sample - with the use of a loading bar-projectile, which, at the moment of impact, has accumulated kinetic energy many times greater than the work of elasto-plastic deformation of this sample; in this case, the speed of the bar-projectile is constant or changes slowly during the entire process of elasto-plastic deforma- tion of the sample on the front of the Hopkinson measuring bar (Figure 9);

$$
\begin{gathered}
v_{s}(t)=c_{0, H} \cdot \varepsilon_{t}(t) \\
\dot{\varepsilon}_{s}(t)=\frac{1}{L_{1}} \cdot\left[v_{0}-v_{s}(t)\right] \\
\varepsilon_{s}(t)=\frac{1}{L_{1}} \cdot\left[v_{0} \cdot t-c_{0, H} \cdot \int_{0}^{t} \varepsilon_{t}(t) d t\right] \\
\sigma_{s}(t)=E_{H} \cdot\left(\frac{D_{H}}{D_{1}}\right)^{2} \cdot \varepsilon_{t}(t)
\end{gathered}
$$

where:

- $L_{1}$ is initial length of the short cylindrical specimen; 


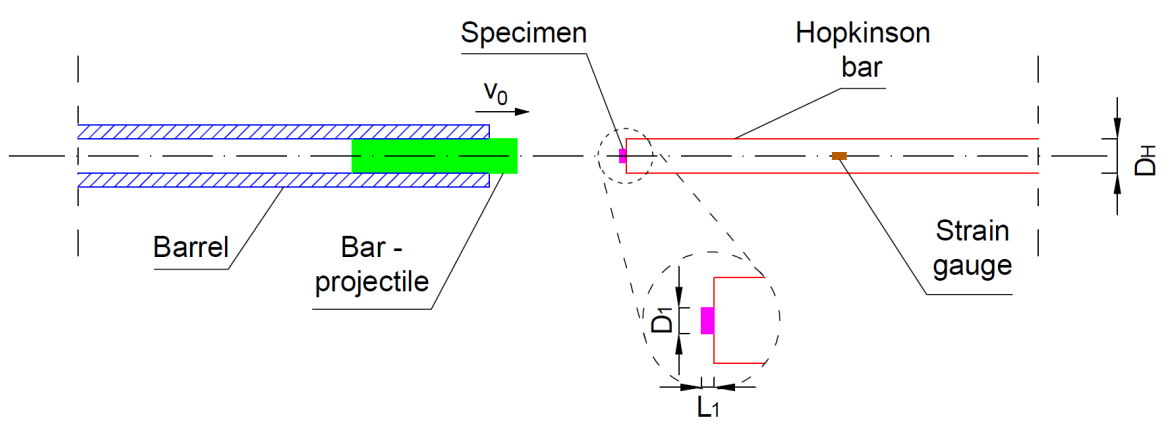

FIGURE 9. Scheme of direct compression in variant I - miniature short cylindrical sample.

- $\varepsilon_{t}(t)$ is elastic positive incident strain pulse in the measuring Hopkinson bar, registered by a strain gauge after passing the compressive loading wave through the specimen;

- $D_{H}$ and $D_{1}$ are initial diameters of the measuring Hopkinson bar and the specimen, respectively;

- $E_{H}$ is Young's modulus of the measuring Hopkinson bar;

- $c_{H}$ is sound velocity in the measuring Hopkinson bar;

- $\sigma_{s}$ is engineering stress in the specimen obtained as a function of time in the assumption of equality of forces at the ends of the specimen during the entire deformation process;

- $\varepsilon_{s}$ is engineering strain in the specimen tested;

- $d o t \varepsilon_{s}$ is engineering strain rate of the specimen tested.

(b) variant II - with the use of a bar-projectile with a much lower mass than in variant I (about $50 \%$ mass of a bar-projectile in variant I); the process of dynamic loading of the sample is wavelike in the case of the bar-projectile - sample Hopkinson measuring bar system (Figure 10;

$$
\begin{gathered}
v_{s}(t)=v_{0}(t)-2 \cdot c_{0, H} \cdot \varepsilon_{t}(t) \\
\dot{\varepsilon}_{s}(t)=\frac{1}{L_{2}} \cdot\left[v_{0}-2 \cdot c_{0, H} \cdot \varepsilon_{t}(t)\right] \\
\varepsilon_{s}(t)=\frac{1}{L_{2}} \cdot\left[v_{0} \cdot t-2 \cdot c_{0, H} \cdot \int_{0}^{t} \varepsilon_{t}(t) d t\right] \\
\sigma_{s}(t)=E_{H} \cdot\left(\frac{D_{H}}{D_{2}}\right)^{2} \cdot \varepsilon_{t}(t)
\end{gathered}
$$

where:

signs and symbols as in point ((1.).a.)
(2.) Taylor impact test - a long cylindrical sampleprojectile fired by a pneumatic launcher hits directly on the front of a Hopkinson measuring bar and undergoes an inhomogeneous elastic-plastic deformation (Figure 11.

$$
\begin{gathered}
\sigma_{y}^{T}=\frac{\left(L_{0}-L_{p l}\right) \cdot \rho \cdot v_{0}^{2}}{2 \cdot\left(L_{0}-L_{1}\right) \cdot \ln \left(\frac{L_{0}}{L_{p l}}\right)}[12] \\
\sigma_{y}^{W G}=\frac{\rho \cdot v_{0}^{2}}{2 \cdot \ln \left(\frac{\left(L_{0}-L_{p l}\right.}{\left(L_{1}-L_{p l}\right)}\right.}[12 \\
\dot{\varepsilon}_{s}=\frac{v_{0}}{2 \cdot\left(L_{0}-L_{e l}\right)}
\end{gathered}
$$

where:

- $L_{0}$ is initial length of specimen;

- $L_{1}$ is compressed (final) length of specimen;

- $L_{p l}$ is length of a section of the specimen along its axis where only plastic deformation occurred;

- $L_{e l}$ is length of a section of the specimen along its axis where only elastic deformation occurred;

- $\sigma_{y}$ is engineering yield stress (upper index $T$ according to the Taylor formula, upper index $W G$ - according to the Wilkins and Guinan formulation);

- $v_{0}$ is impact velocity;

- $\rho$ is mass density of specimen.

The above formulas describing the real (true) measures of stress $\sigma_{t}$, strain $\varepsilon_{t}$ and strain rate $\dot{\varepsilon}_{t}$ of the tested samples in variants I and II have the following forms, respectively:

$$
\begin{gathered}
\dot{\varepsilon}_{t}(t)=\frac{\dot{\varepsilon}_{e}}{1+\varepsilon_{e}(t)} \\
\varepsilon_{t}(t)=\ln \left[1+\varepsilon_{e}(t)\right]
\end{gathered}
$$

$$
\sigma_{t}(t)=\sigma_{e}(t) \cdot\left[1+\varepsilon_{e}(t)\right]
$$




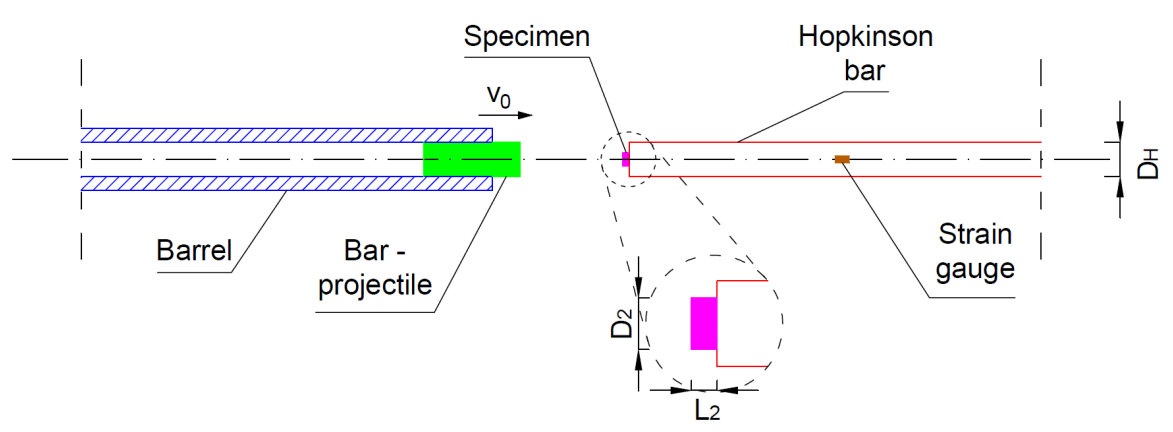

FIGURE 10. Scheme of direct compression in variant II - short cylindrical sample.
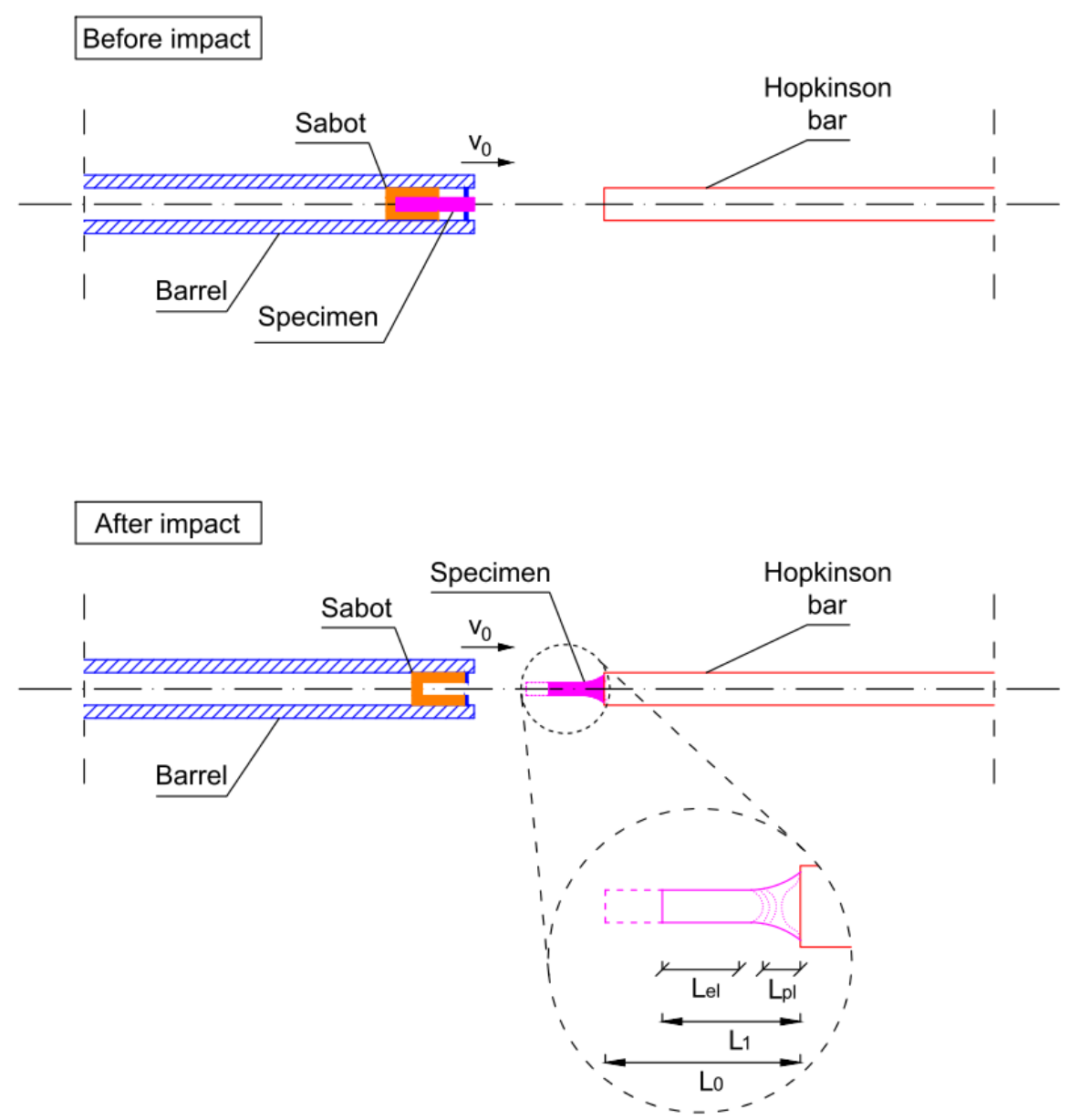

Figure 11. The scheme of the Taylor test - a long cylindrical sample before and after the test (isolines of permanent plastic deformations are marked on the longitudinal section of the sample). 


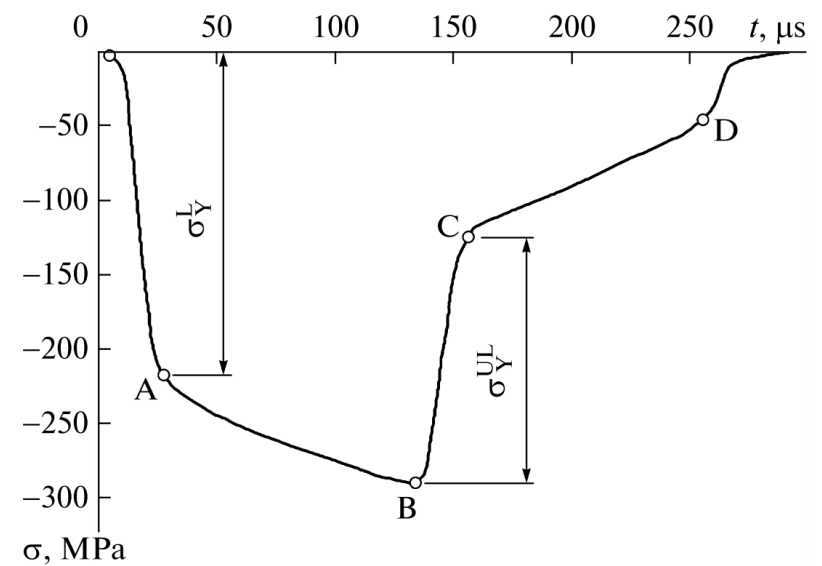

Figure 12. A typical course of the elastic strain impulse in the Hopkinson measuring bar for the determination of the yield strength of the tested metal for a dynamic loading $\sigma_{y}^{L}$ and unloading $\sigma_{y}^{U L}$ [27].

The direct compression test of a short cylindrical sample (variant II) also allows to determine the dynamic Bauschinger effect $\delta$ of the tested metal. The paper 20] presents a method of determining the measure of this effect using this shock test, using the registration of the compressive elastic deformation in time in the Hopkinson measuring bar for this purpose.

Figure 12 shows a typical course of an elastic strain pulse in this measuring rod. From this diagram, the initial dynamic yield limits can be determined: $\sigma_{y}^{L}$ during loading and $\sigma_{y}^{U L}$ during unloading - the differences between the points: between 0 and $\mathrm{B}$, and between $\mathrm{B}$ and $\mathrm{C}$. The calculation of the dynamic Bauschinger effect $\delta$ is determined from the relationship:

$$
\delta=\frac{\sigma_{y}^{U L}}{\sigma_{y}^{L}} .
$$

\section{Conclusions}

The characteristics of the operation of a pneumatic launcher for the purpose of conducting direct impact tests with the use of a bar-projectile and a Hopkinson measuring bar are presented.

The obtained results of the experimental calibration of the pneumatic launcher - loading bar-projectiles characterize the performance of a given essential element of the SHPB set-up, which is significant for conducting various impact direct tests, including the Taylor one.

Schemes of two impact tests with the use of the pneumatic launcher and the Hopkinson measuring bar are presented as noteworthy for dynamic testing of metals in various typical compression modes, which allow to determine their real impact resistance - two variants of direct compression of a short cylindrical sample, including miniature, and a long cylindrical samples, which can also be used as projectiles in the Taylor test. For these tests, relationships were given that allow to determine the nominal (engineering) and real (true) values of stress $\sigma$, strain $\varepsilon$ and strain rate $\dot{\varepsilon}$ as well as the initial dynamic yield strength $\sigma_{y}$ in the version proposed by Taylor $\sigma_{y}^{T}$ and Wilkins and Guinan $\sigma_{y}^{W G}$. Direct compression of a short cylindrical sample also allows to measure the dynamic Bauschinger effect $\delta$.

\section{ACKNOWLEDGEMENTS}

The authors would like to thank Marcin Sokolnicki for his assistance in conducting the physical experiments presented in this paper, i.e., the experimental calibration of the pneumatic launcher.

\section{REFERENCES}

[1] D. M. Hansen. Zalinski's dynamite gun. Technology and Culture 25(2):264-279, 1984. https://doi.org/10.2307/3104714

[2] A. Zbrowski. Badania prototypu działa pneumatycznego. Problemy Eksploatacji 3:217-234, 2011.

[3] K. Sobczyk, L. Kruszka, R. Chmielewski, R. Rekucki. Selected technical and legal aspects of the pneumatic launcher operation for Hopkinson measuring bars set. Inżynieria Bezpieczeństwa Obiektów Antropogenicznych (3):163-172, 2020.

https://doi.org/10.37105/iboa.76

[4] K. Sobczyk, R. Chmielewski, L. Kruszka. The concept of experimental research on the behavior of sand cover material for protective shelters for civilians. Inżynieria Bezpieczeństwa Obiektów Antropogenicznych (1):11-16, 2020. https://doi.org/10.37105/iboa.51

[5] J. Falta, P. Zlámal, M. Adorna. Instrumentation of Split Hopkinson Pressure Bar for testing of cellular metallic materials. Acta Polytechnica CTU Proceedings 18:10-14, 2018. https://doi.org/10.14311/APP.2018.18.0010

[6] M. Adorna, P. Zlámal, T. Fíla, et al. Testing of hybrid nickel-polyurethane foams at high strain-rates using Hopkinson bar and digital image correlation. Acta Polytechnica CTU Proceedings 18:72-76, 2018. https://doi.org/10.14311/APP.2018.18.0072

[7] P. E. Markovsky, J. Janiszewski, V. I. Bondarchuk, et al. Effect of strain rate on microstructure evolution and mechanical behavior of titanium-based materials. Metals 10(11):1404, 2020. https://doi.org/10.3390/met10111404

[8] R. Panowicz, J. Janiszewski, K. Kochanowski. Effects of sample geometry imperfections on the results of split Hopkinson pressure bar experiments. Experimental Techniques 43:397-403, 2019. https://doi.org/10.1007/s40799-018-0293-7

[9] W. Moćko, C. Kostrzewski, A. Brodecki. Influence of anisotropy on the viscoplastic properties of a hot rolled Ti6Al4V titanium alloy. Archives of Metallurgy and Materials 63:403-411, 2018. https://doi.org/10.24425/118954 
[10] H. M. An, L. Liu. Numerical study of dynamic behaviors of concrete under various strain rates. Archives of Civil Engineering LXV(4):21-36, 2019. https://doi.org/10.2478/ace-2019-0044.

[11] M. Li, X. Mao, L. Cao, H. Pu. Influence of heating rate on the dynamic mechanical performance of coal measure rocks. International Journal of Geomechanics 17(8), 2017. https :

//doi.org/10.1061/(ASCE) GM.1943-5622.0000888

[12] Y. Lv, J. Liu, Z. Xiong. One-dimensional dynamic compressive behavior of dry calcareous sand at high strain rates. Journal of Rock Mechanics and Geotechnical Engineering 11(1):192-201, 2019. https://doi.org/10.1016/j.jrmge.2018.04.013

[13] S. Wen, C. Zhang, Y. Chang, P. Hu. Dynamic compression characteristics of layered rock mass of significant strength changes in adjacent layers. Journal of Rock Mechanics and Geotechnical Engineering 12(2):353-365, 2020. https://doi.org/10.1016/j.jrmge.2019.09.003

[14] J. Xu, Y. Kang, Z. Wang, X. Wang. Dynamic mechanical behavior of granite under the effects of strain rate and temperature. International Journal of Geomechanics 20(2), 2020. https:

//doi.org/10.1061/(ASCE) GM.1943-5622.0001583

[15] R. Chmielewski, L. Kruszka, R. Rekucki, K. Sobczyk. Experimental investigation of dynamic behavior of silty sand. Archives of Civil Engineering LXVII(1):481-498, 2021. https://doi.org/10.24425/ACE. 2021.136484.

[16] A. M. Bragov, L. A. Igumnov, A. Y. Konstantinov, et al. Methodological aspects of testing brittle materials using the split Hopkinson bar technique. Strain p. e12389, 2021. https://doi.org/10.1111/str.12389.

[17] G. Ryzińska, R. Gieleta. Effect of test velocity on the energy absorption under progressive crushing of composite tubes. Advances in Science and Technology Research Journal 14(2):94-102, 2020. https://doi.org/10.12913/22998624/118551.

[18] D. Miedzińska, R. Gieleta, E. Małek. Experimental study of strength properties of SLA resins under low and high strain rates. Mechanics of Materials 141:103245, 2020. https://doi.org/10.1016/j.mechmat.2019.103245
[19] A. Papliński. Assessment of threat arising by the exploitation of acetylene. Inżynieria Bezpieczeństwa Obiektów Antropogenicznych (3):198-211, 2020. https://doi.org/10.37105/iboa.78

[20] A. Baryłka. Zagadnienie zdatności obiektów budowlanych do użytkowania w problematyce inżynierii bezpieczeństwa tych obiektów. Inżynieria Bezpieczeństwa Obiektów Antropogenicznych (4), 2019. https://doi.org/10.37105/iboa.31

[21] U. Lindholm. Some experiments with the SplitHopkinson Pressure Bar. Journal of the Mechanics and Physics of Solids 12(5):317-335, 1964. https://doi.org/10.1016/0022-5096(64)90028-6.

[22] Announcement of the Marshal of the Sejm of the Republic of Poland of May 15, 2020, on the publication of the consolidated text of the Act on weapons and ammunition (in Polish). Dz. U. 2020 poz. 955.

[23] Act of June 13, 2019, on the performance of an economic activity in the field of production and trade in explosives, weapons, ammunition, as well as products and technology for military or police purposes (in Polish). Dz. U. 2019 poz. 1214.

[24] Regulation of the Council of Ministers of September 17, 2019, on the classification of types of explosives, weapons, ammunition, and products and technologies for military or police purposes, the production or trade of which requires a license (in Polish). Dz. U. 2019 poz. 1888.

[25] C. M. A. Silva, P. A. R. Rosa, P. A. F. Martins. An innovative electromagnetic compressive split Hopkinson bar. International Journal of Mechanics and Materials in Design 5(3):281-288, 2009. https://doi.org/10.1007/s10999-009-9101-y.

[26] S. J. Hiermaier. Structures under crash and impact. Continuum mechanics, discretization and experimental characterization. Springer, 2010. ISBN 978-1-4419-4479-5.

[27] A. M. Bragov, A. Y. Konstantinov, A. K. Lomunov. Determining the Bauschinger effect using the direct impact technique. Technical physics letters 36(8):694-695, 2010. https://doi.org/10.1134/S1063785010080043. 